\title{
The Role of Steroid Receptors and HER2 in Ovarian Cancer
}

\section{Maria Carolina de Toledo and Amilcar Barreta*}

Department of Obstetrics and Gynecology, Faculty of Medical Sciences, State University of Campinas - UNICAMP, Campinas, Brazil

Ovarian cancer is one of the most lethal female malignancies. Despite of all the efforts in surgery and chemotherapy, advanced disease, which is the majority of the cases at the time of diagnosis, is associated with poor survival [1]. Besides, epithelial ovarian cancer (EOC) is a disease with great heterogeneity; so, the determination of individual tumor characteristics can be associated with different clinical behavior and may have impact on treatment and prognosis.

Tumor cells do interact with the environment around them [2]. In recent years, with the development of the molecular biology and immunologic methods, molecules such as the human epidermal growth factor receptor type 2 (HER2), and the steroid receptors, estrogen (ER), progesterone (PR) and androgen (AR), have been tested as potential biomarkers of individualized clinical behavior of cancer.

The effect of steroid hormones in carcinogenesis has been studied specially for breast and endometrial cancer with well-known and promising results for therapy. However for ovarian cancer these results have been conflicting and unclear [3,4]. While the expression of PR has been shown to predict better prognosis with apoptotic effect [5], a positive ER status has shown discrepant results [6-8]depending on the subtype of ER and tumor type [9]. In recurrent low-grade carcinoma of the ovary or peritoneum, hormonal therapies had a greater anti-tumor activity in $\mathrm{ER}+/ \mathrm{PR}+$ patients than in ER+/PR- patients; although it was not statistical significant [10]. The status of the AR and HER2 in ovarian cancer has also showed unclear results. Bookman and colleagues described a limited clinical value of trastuzumab in recurrent ovarian cancer because of the low frequency of HER2 overexpression [1114]. Also at study, the subgroup of "triple negative epithelial ovarian cancer" (TNEOC), i.e., tumors that do not express ER (subtype alpha-ER), PR and HER2, may be significantly more aggressive and display a poorer prognosis than non-TNEOC tumors [15], similarly as evidenced in studies for breast cancer [16]. A recent review and meta-analysis of behavior found that PR predicted favorable survival, while HER2 expression had a negative effect on survival. ER expression remains controversial suggesting a protector effect especially of ER $\beta$ expression which data was limited by the sample size [17]. Although all this conflicting data is true to some extent it is important to emphasize that most ovarian cancer biomarker studies are not subtype specific and this can lead to misleading results [18]. In 2013, Sieh and colleagues published a collaborative study with 2933 women and analyzed hormonal-receptor expression by tumor subtype and ovarian cancer survival. They found that PR positivity was associated with disease-specific survival in endometrioid carcinoma and high-grade serous carcinoma and ER positivity was associated with disease-specific survival in endometrioid carcinoma. No significant associations were found for mucinous, clear-cell or low-grade serous carcinoma [19].

Recently our group published a study which analyzed the contribution of the expression of ER ( $\alpha$ and $\beta$ ), PR, AR and HER2 and "triple-negative" tumor status to disease-free and overall survival in 152 women with epithelial ovarian cancer [20]. Our results showed that women with $\mathrm{ER} \alpha$ positivity had a greater disease free-survival but had no effect on overall survival. However, this result was not subtype- specific and hormonal expression in these patients should be analyzed by tumor subtype as Sieh did for clearer results. The previous reported findings about TNEOC were not observed at our study, so those controversies still persist.

In conclusion, ovarian cancer subtypes are different diseases. These differences lead to heterogeneous responses to treatment. So, biomarker studies should be stratified by subtype to establish whether hormone-receptor status predicts behavior in EOC, and whether it could guide to personalised treatment for ovarian cancer, such as endocrine treatment.

\section{References}

1. Hunn J, Rodriguez GC (2012) Ovarian cancer: etiology, risk factors, and epidemiology. Clin Obstet Gynecol 55: 3-23.

2. Giles JR, Elkin RG, Trevino LS, Urick ME, Ramachandran R, et al. (2010) The restricted ovulator chicken: a unique animal model for investigating the etiology of ovarian cancer. Int J Gynecol Cancer 20: 738-744.

3. Liu N, Wang $X$, Sheng $X$ (2011) 'Triple negative' epithelial ovarian cancer and pathologic markers for prognosis. Curr Opin Obstet Gynecol 23: 19-23.

4. Kommoss F, Pfisterer J, Geyer H, Thome M, Sauerbrei W, Pfleiderer A (1991) Estrogen and progesterone receptors in ovarian neoplasms: discrepant results of immunohistochemical and biochemical methods. Int J Gynecol Cancer 1: 147-153.

5. Lee P, Rosen DG, Zhu C, Silva EG, Liu J (2005) Expression of progesterone receptor is a favorable prognostic marker in ovarian cancer. Gynecol Oncol 96: 671-677.

6. Halon A, Nowak-Markwitz E, Maciejczyk A, Pudelko M, Gansukh T, et al. (2011) Loss of estrogen receptor beta expression correlates with shorter overall survival and lack of clinical response to chemotherapy in ovarian cancer patients. Anticancer Res 31: 711-718.

7. Sallum LF, Sarian LO, Lucci De Angelo Andrade L, Vassallo J, Soares FA, et al. (2013) Survival of women with ovarian carcinomas and borderline tumors is not affected by estrogen and progesterone receptor status. J Gynecol Oncol 24: $167-176$

8. De Stefano I, Zannoni GF, Prisco MG, Fagotti A Tortorella L, et al. (2011) Cytoplasmic expression of estrogen receptor beta $(E R \beta)$ predicts poor clinical outcome in advanced serous ovarian cancer. Gynecol Oncol 122: 573-579.

9. Burges A, Brüning A, Dannenmann C, Blankenstein T, Jeschke U, et al. (2010) Prognostic significance of estrogen receptor alpha and beta expression in human serous carcinomas of the ovary. Arch Gynecol Obstet 281: 511-517.

10. Gershenson DM, Sun CC, lyer RB, Malpica AL, Kavanagh JJ, et al. (2012) Hormonal therapy for recurrent low-grade serous carcinoma of the ovary or peritoneum. Gynecol Oncol 125: 661-666.

*Corresponding author: Amilcar Barreta, PO Box 6111 State University of Campinas, UNICAMP, Zip Code 13083-970, Campinas, SP, Brazil, Tel: +55 19 991198210; E-mail: abarreta@yahoo.com.br

Received December 10, 2013; Accepted January 22, 2014; Published January 27, 2014

Citation: de Toledo MC, Barreta A (2014) The Role of Steroid Receptors and HER2 in Ovarian Cancer. J Carcinog Mutagen 5: 158. doi:10.4172/2157-2518.1000158

Copyright: (c) 2014 de Toledo MC, et al. This is an open-access article distributed under the terms of the Creative Commons Attribution License, which permits unrestricted use, distribution, and reproduction in any medium, provided the original author and source are credited. 
Citation: de Toledo MC, Barreta A (2014) The Role of Steroid Receptors and HER2 in Ovarian Cancer. J Carcinog Mutagen 5: 158. doi:10.4172/21572518.1000158

11. Motamed-Khorasani A, Jurisica I, Letarte M, Shaw PA, Parkes RK, et al. (2007) Differentially androgen-modulated genes in ovarian epithelial cells from BRCA mutation carriers and control patients predict ovarian cancer survival and disease progression. Oncogene 26: 198-214.

12. Nodin B, Zendehrokh N, Brändstedt J, Nilsson E, Manjer J, et al. (2010) Increased androgen receptor expression in serous carcinoma of the ovary is associated with an improved survival. J Ovarian Res 3: 14

13. Hoopmann M, Sachse K, Valter MM, Becker M, Neumann R, et al. (2010) Serological and immunohistochemical HER-2/neu statuses do not correlate and lack prognostic value for ovarian cancer patients. Eur J Cancer Care (Engl) 19: 809-815.

14. Bookman MA, Darcy KM, Clarke-Pearson D, Boothby RA, Horowitz IR (2003) Evaluation of monoclonal humanized anti-HER2 antibody, trastuzumab, in patients with recurrent or refractory ovarian or primary peritoneal carcinoma with overexpression of HER2: a phase II trial of the Gynecologic Oncology Group. J Clin Oncol 21: 283-290.
15. Liu N, Wang X, Sheng X (2010) The clinicopathological characteristics of 'triplenegative' epithelial ovarian cancer. J Clin Pathol 63: 240-243.

16. Chacón RD, Costanzo MV (2010) Triple-negative breast cancer. Breast Cancer Res 12: S3.

17. Zhao D, Zhang F, Zhang W, He J, Zhao Y, et al. (2013) Prognostic role of hormone receptors in ovarian cancer: a systematic review and meta-analysis. Int J Gynecol Cancer 23: 25-33.

18. Köbel M, Kalloger SE, Boyd N, McKinney S, Mehl E, et al. (2008) Ovarian carcinoma subtypes are different diseases: implications for biomarker studies. PLoS Med 5: e232.

19. Sieh W, Köbel M, Longacre TA, Bowtell DD, deFazio A, et al. (2013) Hormonereceptor expression and ovarian cancer survival: an Ovarian Tumor Tissue Analysis consortium study. Lancet Oncol 14: 853-862.

20. de Toledo MC, Sarian LO, Sallum LF, Andrade LL, Vassallo J, et al. (2013) Analysis of the contribution of immunologically-detectable HER2, steroid receptors and of the "triple-negative" tumor status to disease-free and overall survival of women with epithelial ovarian cancer. Acta Histochem.
Citation: de Toledo MC, Barreta A (2014) The Role of Steroid Receptors and HER2 in Ovarian Cancer. J Carcinog Mutagen 5: 158. doi:10.4172/21572518.1000158
Submit your next manuscript and get advantages of OMICS Group submissions

Unique features:

- User friendly/feasible website-translation of your paper to 50 world's leading languages

Audio Version of published paper

Digital articles to share and explore

Special features:

300 Open Access Journals

25,000 editorial team

21 days rapid review process

Quality and quick editorial, review and publication processing

Indexing at PubMed (partial), Scopus, EBSCO, Index Copernicus and Google Scholar etc

- Sharing Option: Social Networking Enabled

- Authors, Reviewers and Editors rewarded with online Scientific Credits

Better discount for your subsequent articles

Submit your manuscript at: http://www.omicsonline.org/submission 